\title{
LYMPHOCYTIC THYMOMA IN CAVALIER KING CHARLES SPANIEL - CASE REPORT AND REVIEW
}

\author{
G. Simeonova ${ }^{1}$, V. Nedev ${ }^{1 *}$, R. Simeonov ${ }^{2}$ \\ ${ }^{1}$ Department of Veterinary Surgery, Faculty of Veterinary Medicine, Trakia University, Stara Zagora, \\ Bulgaria \\ ${ }^{2}$ Department of General and Clinical Pathology, Faculty of Veterinary Medicine, Trakia University, \\ Stara Zagora, Bulgaria
}

\begin{abstract}
A clinical case of thymoma in 6 month old, male, cavalier King Charles spaniel was described. The patient was brought to the Small Animal Clinic of Veterinary faculty at Trakia University, Stara Zagora in order to be evaluated by means of electroretinography (ERG) because of vision loss and difficulties in orientation in unfamiliar surroundings. Physical examination did not reveal any disturbances in vital parameters neither in retinal function. As complications occurred during recovery from general anaesthesia more detailed investigations were performed and the diagnosis thymoma was made. It was confirmed pathohistologically.

Thymoma is an extremely rare tumor in dogs, especially in cavalier King Charles spaniels. The unusual manifestation of the disease as well as its very rare distribution among dogs was the reason to give a problem consideration.
\end{abstract}

Key word: thymoma, cavalier King Charles spaniel, dog

\section{INTRODUCTION}

The thymus is a lymphoepithelial organ, which function is development and differentiation of $\mathrm{T}$ cells. After the puberty, thymic gland atrophies but its remnants may undergo neoplastic proliferations (1). Thymoma is a neoplasm of thymic epithelium in which there are various degrees of lymphocytic infiltration (2). Although thymomas in humans are well documented and classified histopathologically, it is an uncommon tumor in animals that has been reported in just a few species $(3,4)$. Thymomas seem to occur at a relatively high prevalence in cats (5), dairy goats (6) and laboratory rodents (7). In other animal species they are considered as very rare. Most are benign, but malignant thymomas have also been reported in animals (8). Distant metastases are also unusual findings (9). In domestic animals thymomas have not been classified in details (10). There is a classification based only on density of

\footnotetext{
* Correspondence to: Vladi Nedev, Department of Veterinary Surgery, Faculty of Veterinary

Medicine, Trakia University, Stara Zagora 6000,

Bulgaria ; E-mail: vladi_nedev@mail.bg
}

lymphocytes within the neoplasm, resulting in three histologic subtypes: epithelial predominant, lymphocyte predominant or mixed type (4).

\section{CASE REPORT}

A 6-months-old, male, cavalier King Charles spaniel dog was presented in Small Animal Clinic of Veterinary faculty at Trakia University, Stara Zagora on the $6^{\text {th }}$ of January 2015 for routine electroretinographic (ERG) examination, because of vision loss and difficulties in orientation in unfamiliar surroundings. Clinical examination showed the following data: body temperature $-38.0{ }^{\circ} \mathrm{C}$; heart rate -128 beats/min; respiratory rate -25 movements/min, and shallow breathing. The mucous membrane colour was pink with normal surface. The patient stayed in one and the same place unwilling to move. This behavior was attributed to visual deficiency. Blood sample was taken for haematological and biochemical examination. The results are presented on Table 1. 
SIMEONOVA G., et al.

Table 1. Haematological and biochemical parameters measured in dog with thymoma

\begin{tabular}{|c|c|c|}
\hline Marker & Measured value & Reference values \\
\hline $\mathrm{Hb}, \mathrm{g} / \mathrm{l}$ & 101 & $120-180$ \\
\hline $\mathrm{Er}, \mathrm{T} / \mathrm{l}$ & 4.31 & $5.5-8.5$ \\
\hline Hct, \% & 28.7 & $37-55$ \\
\hline Leuc, G/1 & 20.3 & $5-17$ \\
\hline $\mathrm{MCV}, \mathrm{fl}$ & 56,7 & $50-80$ \\
\hline PLT, G/1 & 23 & $160-430$ \\
\hline $\mathrm{Ca}, \mathrm{mmol} / \mathrm{l}$ & 3.33 & $2.4-2.8$ \\
\hline $\mathrm{P}, \mathrm{mmol} / \mathrm{l}$ & 2.12 & $0.94-1.52$ \\
\hline $\mathrm{Mg}, \mathrm{mmol} / \mathrm{l}$ & 0.81 & j.6-1.1 \\
\hline Total protein, $\mathrm{g} / \mathrm{l}$ & 58.3 & $54-78$ \\
\hline Glucose, $\mathrm{mmol} / \mathrm{l}$ & 5.62 & $3-6.1$ \\
\hline AST, U/l & 37 & $15-40$ \\
\hline $\mathrm{ALT}, \mathrm{U} / \mathrm{l}$ & 43 & $15-55$ \\
\hline BUN, mmol/l & 4.1 & $1.7-7.4$ \\
\hline Creatinine, $\mu \mathrm{mol} / 1$ & 57 & $40-120$ \\
\hline Cholesterol, mmol/l & 5.16 & $3.3-9.3$ \\
\hline
\end{tabular}

After the general physical examination a special ophthalmological investigation was performed. The animal was considered as blind. There was no pupil reaction on the left eye, but there was on the right eye. With the aim of led slit lamp (Handy Slit Lamp XL-1, Shin Nippon, Rexxam Co., Ltd.., Japan ) we established that there was a partial depigmentation of both irises. After bilateral mydriasis caused with Mydfrin $^{\circledR}$ (Phenylephrine Hydrochloride, S.A.Alcon, Belgium) 2 drop on each eye we examined the fundus with direct ophthalmoscope (Rudolf Reister GmbH, Germany) and found a lightening of the fundus with hyperreflexia and gray pigmenatation spots on the tapetum nigrum. There was also a hyperemia of the retinal blood vessels. The final part of the specialized examination was electroretino- graphy (ERG). The animal was put on general anaesthesia, using the approved protocol for this examination in the small animal clinic. BPM200 ERG/VER electroretinograph (RetinoGraphics Inc., USA) was used for that purpose. The results revealed that function of the retina was normal. At the end of the examination we noticed some haemoragic exudate leaking from endotrachial tube and 2 $\mathrm{ml}$ of the steroid antiinflammatory drug dexamethazone (Alfasan international B.V., Netherlands ) was administrated IV. Even though, the recovery of the dog from general anaesthesia was problematic. It showed a difficult labored breathing and we decided to make an X-ray. Severe changes in the lung parenchima were found on lateral radiography (Figure 1).

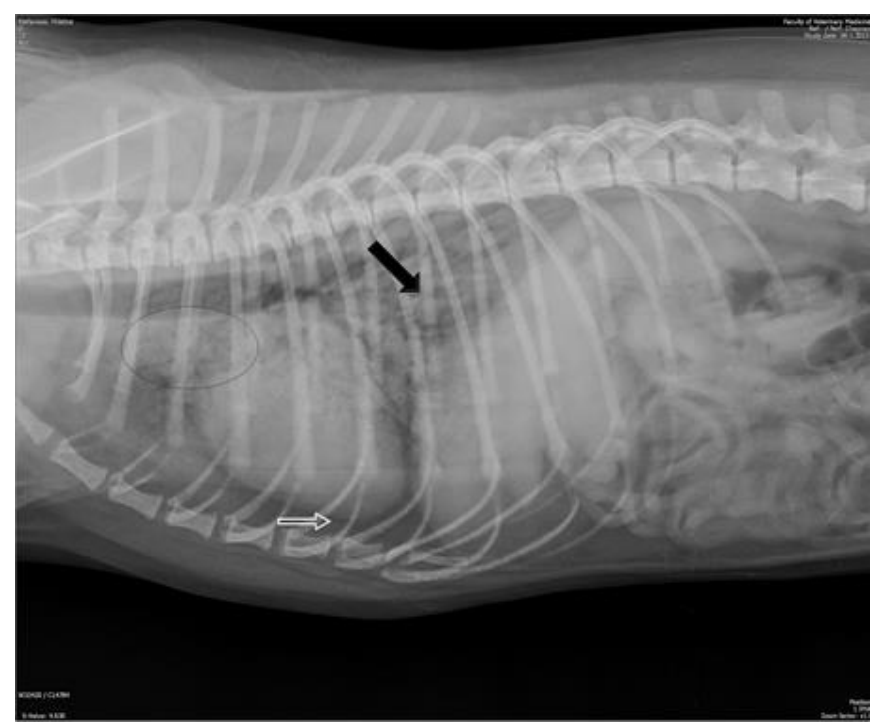

Figure 1. Radiographycally seen changes indicated the presence of small amount of air in the chest (white arrow), that pushed the heart apex up from the sternum. There was a coarse interstitial pattern of the diaphragmal lobes and intense shadows throughout the whole parenchima (black arrow) suggesting new tissue growth. Cranially from the heart there was a mass (circle) with size of an egg and dense structure. 
Soon after extubation the breathing stopped and animal was intubated again. Artificial ventilation with $100 \%$ oxygen was initiated immediately. While the patient was on assisted breathing, its heart had stopped and we started reanimation using ephedrin (Ephedrine Sopharma ${ }^{\circledR} 50 \mathrm{mg} / \mathrm{ml}$, Sopharma AD, Bulgaria) 0,1 mg/kg IV. Cardio-pulmonary resuscitation continued with an administration of atropine sulfas (Atropin Sopharma ${ }^{\circledR} 1$ $\mathrm{mg} / \mathrm{ml}$., Sopharma AD, Bulgaria ) 0,05 mg/kg IV, adrenaline (Adrenaline Sopharma ${ }^{\circledR}$ $1 \mathrm{mg} / \mathrm{ml}$, Sopharma AD, Bulgaria) 0,02 mg/kg IV, glucocoffein (Glucocoffein 10\%, VetProm, Radomir, Bulgaria) $10 \mathrm{ml}$ IV and Ringer solution (Ringer Braun, B.Braun Melsungen AG, Germany) $40 \mathrm{ml} / \mathrm{kg} / \mathrm{h}$ IV. The dog came out of the cardiovascular and pulmonary arrest but only temporarily. The animal was unstable and after several hours of intensive reanimation the patient died. Necropsy was made and the metastatic thymoma was diagnosed.
Tissue samples were taken and fixed in $10 \%$ neutral formalin solution for histological investigation and processed by classical histological techniques $(11,12)$. The resulting slices with a thickness of $4 \mu \mathrm{m}$ were stained with hematoxylin-eosin (H\&E).

Pathohistological findings showed abundance of lymphocytes as a prevailing cell type in tumor parenchyma - lymphocytic thymoma (Figure 2). Epithelial cells were elongated spindle shaped. Round-oval to polygonal cells were rarely watched. Cytoplasmic boundaries were unclear. Vesiculated nuclei were stained and pale. Occasionally, single mast cells, eosinophils, macrophages, plasma cells and neutrophils were visualized in tumor parenchyma, which is considered a normal finding. On some sections of the preparation appeared so called Corpuscles of Hassal (concentric groups of epithelial cells with eosinophilic cytoplasm), which according to some authors could be considered a specific finding for thymoma (Figure 3).

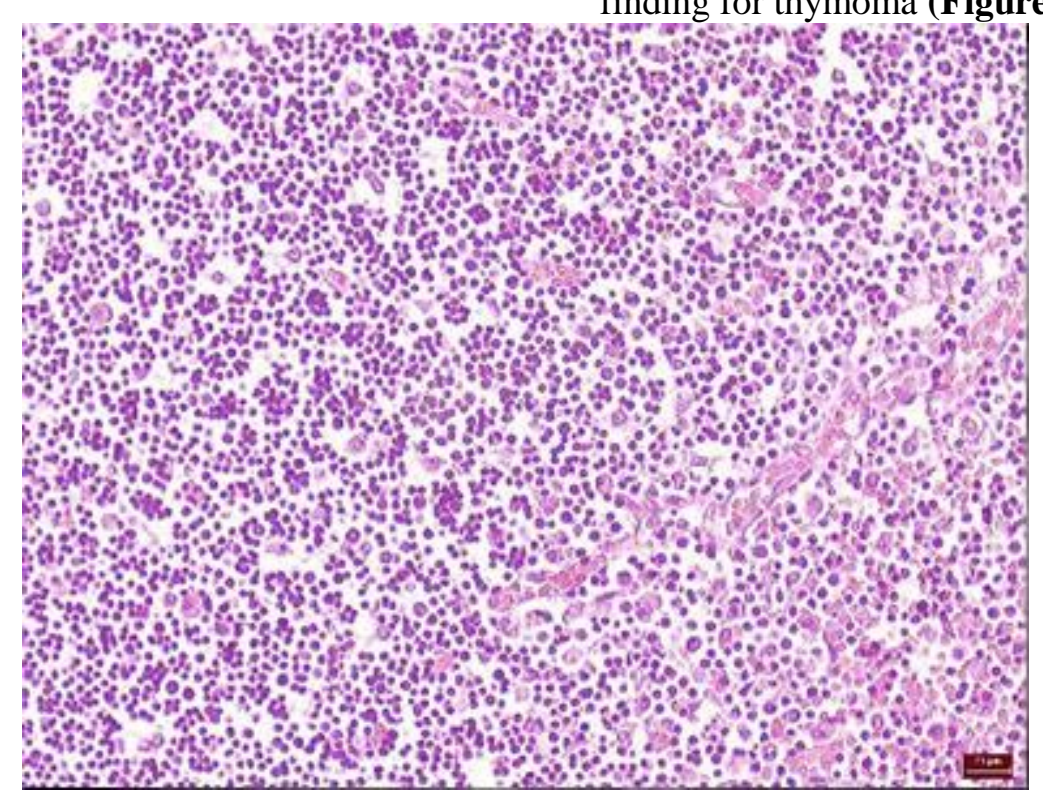

Figure 2. Lymphocytic thymoma in a dog. Predominant lymphocytes in tumous parenchima. H\&E staining.

\section{DISCUSSION}

Canine thymoma is very rare disease, accounting for $20 \%$ of thymic pathology in dogs (13), that affects mostly large breeds such as Labrador Retriever, Golden Retriever (14) and German shepherd (13, 15). Thymoma may occur at any age but usually affects older patients. The reported peak for clinical presentation is 9 years in dogs and 10 years in cats, respectively (3). The minimum age reported was 2.5 years (9). In cows, thymomas occur mostly in animals over 3 years old (16). Some reports regarding strains of rats, which are used as experimental animals, have described that thymomas are not observed in any animals younger than 2 years (17).Our case describes thymoma in dog from uncommon breed and unusual age. The diagnose was made on the base of typical microscopic findings, such as abundance of lymphocytes and neoplastic epithelial cells that are commonly elongate or spindled, mixed with round to polygonal cells (18). Hassall's corpuscles usually present when the materials are fixed with formalin and stained with hematoxylin-eosin (H\&E) (19). Some researchers have described structures resembling Hassall's corpuscles as an uncommon in thymoma (20) but in the present case these structures were seen. 


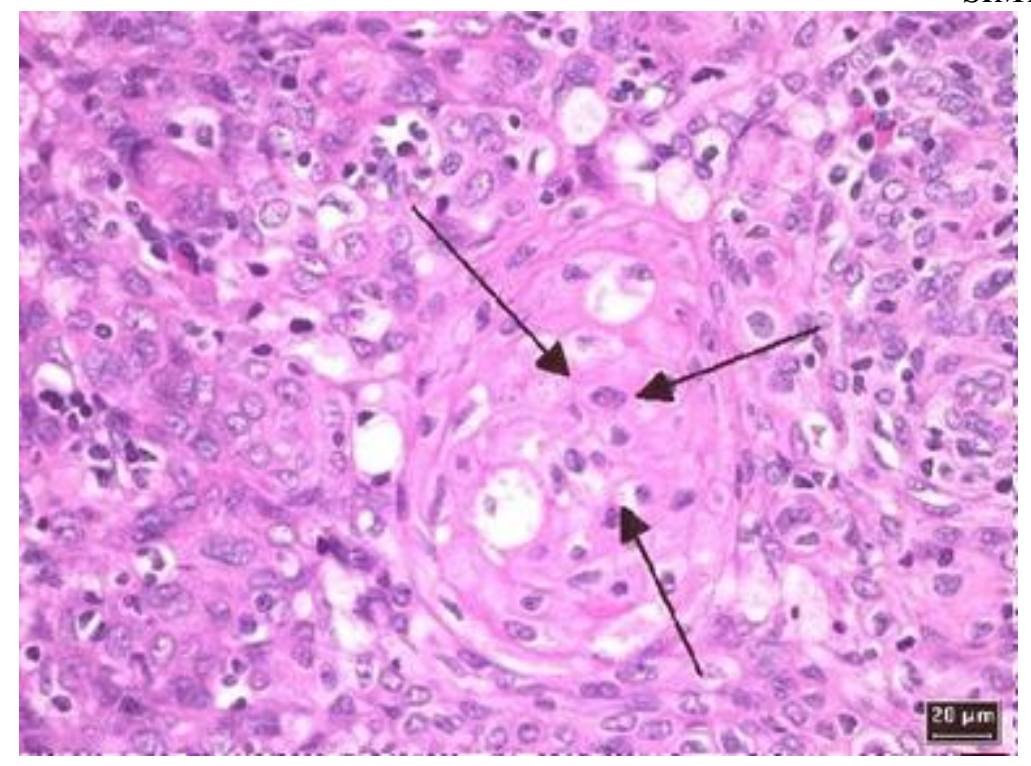

Figure 3. Corpuscles of Hassal (concentric groups of epithelial cells with eosinophilic cytoplasm) (arrows). H\&E staining.

Paraneoplastic syndromes like myastenia gravis, exfoliative dermatitis, erythema multiforme, hypercalcemia, T-cell lymphocytosis, anemia and polymiositis are common in dogs and cats (21). In our case we suspected that the dog had myastenia gravis because of the limb weakness but it was not proved with acetylcholine receptor (ACHR) antibody titers for the fast lethal outcome of the animal. Complete blood count is usually normal but anemia and thrombocytopenia, secondary to immune-mediated destruction, may occur. Hypercalcemia, although uncommon, has been reported in association with thymoma $(9,22)$. In the present case results from haematological and biochemical investigations showed anaemia, trombocytopenia and hypercalcemia that confirm the presence of some typical paraneoplastic changes in the blood. Trombocytopenia could be due also to the predisposition of cavalier King Charles spaniel to giant platelet disorder observed in $50 \%$ of this breed population. It is characterized by thrombocytopenia, macrothrombocytes, or decreased platelet aggregation (23). The definitive diagnosis of a thymoma is based on biopsy and histopathological examination (24). Several neoplastic diseases of the thymus in dogs have been described, including lymphoma, metastatic carcinoma, teratoma, schwannoma, mediastinal neuroblastoma, mediastinal lymph node hyperplasia and thymic cysts $(25,26)$.

Thymomas account for $10 \%$ of primary mediastinal neoplasms in man ( 27). The majority of them occurs in elderly patients, 60 years or older without any sex or race predilection (28). Human thymomas are classified into several histological types by the WHO classification based on the cell components and malignancy. Medullary thymoma (type A, Spindle cell thymoma) is composed of a neoplastic thymic epithelium assuming a spindle cell appearance with few thymocytes. Predominantly cortical thymoma (type B1) has a polygonal epithelium and abundant immature thymocytes with medullalike pale areas. These areas are thought to represent medullary differentiation. Cortical thymoma (type B2) is characterized by distinct neoplastic epithelial cells lined among immature thymocytes. Medullary differentiation is absent in this type of thymoma. Mixed thymoma (type $\mathrm{AB}$ ) has both proliferation areas seen in types $\mathrm{A}$ and $\mathrm{B}$. Additionally, well-differentiated thymic carcinoma (type B3) and thymic carcinoma (type C) are also referred to in the WHO classification (29).

The treatment options for thymoma in dogs include thymectomy, chemotherapy, and radiation therapy. Thymectomy is the treatment of choice for noninvasive thymoma without megaesophagus (1). Dogs with thymoma, even those with a large tumor burden or a paraneoplastic syndrome, had a good prognosis following surgery. In the study of Robat Cs et al. (2013) median survival time with and without surgical treatment was 635 and 76 days, respectively. Presence of another tumor at the time of thymoma diagnosis, lack of surgical excision, and higher pathological stage were significantly associated with shorter survival time. Hypercalcemia and the presence of myasthenia gravis or megaesophagus at the time of thymoma diagnosis, histopathologic 
subtype of thymoma, or tumor development at an older age was not associated with survival time (14).

Less than one-third of thymomas are metastatic or malignant rather than they are locally invasive. There are rare reports of distant metastases in the lungs which were connected with fast lethal outcome $(26,30)$.

In conclusion, the present case showed that canine thymoma could affect medium sized breeds such as cavalier King Charles spaniel at young age and may have very unusual clinical presentation which might resemble to blind dog.

\section{REFERENCES}

1. Lainesse, MF., Taylor, SM., Myers, SL., Haines, D., Fowler, JD., Focal myastheis gravis as a paraneoplastic syndrome of canine thymoma: Improvement following thymectomy. $J$ Am Anim Hosp Assoc ,32:111-117,1996.

2. Rosai, J., Levine, GD., Tumors of the thymus. In: Firminger, HI. (eds), Atlas of Tumor Pathology, 2nd series, Washington: Armed Forces Institute of Pathology, 34161, 1976.

3. Parker, GA. and Casey, HW., Thymomas in domestic animals. Vet Pathol., 13: 353364, 1976.

4. Jacobs, R.M., Messick, J.B., Valli, V.E, Tumors of the hemolymphatic system. In: Meuten D.J. (eds), Tumors in domestic animals, 4th ed., Iowa State Press, Ames, IA , 119- 198, 2002.

5. Patnaik, AK., Lieberman, PH., Erlandson, RA., Antonescu, C., Feline cystic thymoma: A clinicopathologic, immunohistologic, and electron microscopic study of 14 cases. J Feline Med Surg, 5:27-35, 2003.

6. Hadlow, W.J., High prevalence of thymoma in the dairy goat-report of seventeen cases. Vet Pathol, 15:153-169, 1978.

7. Stewart, HL.and Snell, KC., Thymomas and thymic hyperplasia in Praomys (Mastomys) natalensis. Concomitant myositis, myocarditis and sialodacryoadenitis. J Natl Cancer Inst, 40:1135-1159, 1968.

8. Aronsohn, MG., Schunk, KL., Carpenter, JL., King, NW., Clinical and pathologic features of thymoma in 15 dogs. J Am Vet Med Assoc, 184:1355-1362, 1984

9. Atwater, SW., Powers, BE., Park, RD., Canine thymomas: 23 cases (1980-1991), $J$ Am Vet Med Assoc, 205:1007-1013, 1994.

10.Valli, VE., Jacobs, RM., Parodi, AL., Vernau, W. and Moore, PF., Histological classification of hematopoietic tumors of domestic animals. In: Schulman, FY. (eds), World Health Organization International Histological Classification of Tumors of Domestic Animals Second Series, Washington, D.C., Armed Forces Institute of Pathology and American Registry of Pathology, 47-48, 2002.

11.Djurov, A., Alexandrova, E. and Aleksandrov, M., Methods for pathological studies. Zemizdat, Sofia, 1989.

12.Dyakov, L., Lozanov, L., Angelov, A. and Stoykov, D., Manual for exercise in veterinary patohistology. Zemizdat, Sofia, 1989

13.Day, M. J., Review of thymic pathology in 30 cats and 36 dogs. J Small Anim Pract, 38(9):393- 403, 1997.

14.Robat, CS., Cesariok, L., Gaeta, R., Miller, M., Schrempp, D. and Chun, R., Clinical features, treatment options, and outcome in dogs with thymoma: 116 cases (19992010). Am Vet Med Assoc., 243(10):144854, 2013.

15.Faisca,P., Henriques,J., Dias,TM., Resende, L. and Mestrinho, L., Ectopic cervical thymic carcinoma in a dog , J Small Anim Pract., 52(5):266-70, 2011.

16. Sandison, AT. and Anderson, LJ., Tumors of the thymus incattle, sheep, and pigs., Cancer Res., 29: 1146-1150, 1969.

17.Kuper, CF., Beems, RB., Bruijntjes, JP., Schuurman, HJ. and Vos, JG., Thymoma. In: Mohr, U., Dungworth, DL .and Capen, CC., (eds). Pathology of the Aging Rat volume 1, Washington, D.C, ILSI Press, 39-41, 1992.

18.Astor, J., Diseases of white blood cells, lymph nodes, spleen, and thymus. In: Cotran, RS., Kumar, V. and Collins, T., (eds) Robbins Pathologic Basis of Disease, 7th ed., W.B. Saunders Company, Philadelphia, 706-711, 2005.

19.Rae, CA., Jacobs, RM.and Couto, CG., A compartion between the cytological and histological characteristics in thirteen canine and feline thymomas., Can Vet J, 30:497-500, 1989 .

20.Robinson, M., Malignant Thymoma with Metastases in a Dog, Vet. Path., 11: 172180,1974 .

21.Zitz, JC., Birchard, SJ., Couto, GC., Samii, VF., Weisbrode, SE. and Young, GS., Results of excision of thymoma in cats and dogs: 20 cases (1984-2005) J Am Vet Med Assoc., 232:1186-1192, 2008 .

22.Foley, P., Shaw, D., Runyon, C., Serum parathyroid hormone-releated protein concentration in a dog with thymoma and 
present hypercalcemia., Can Vet, 41:867870,2000 .

23. Cowan, SM., Bartges, JW., Gompf, RE., Hayes, JR., Moyers, TD., Snider, CC., Gerard, DA., Craft, RM., Muenchen, RA. and Carroll, RC., Giant platelet disorder in the Cavalier King Charles Spaniel., Exp Hematol,. 32(4):344-50, 2004 .

24.Smith, AN., Wright, JC., Brawner, Jr WR., LaRue, SM., Fineman, L., Hogge, GS., Kitchell, BE., Hohenhaus, AE., Burk, RL., Dhaliwal, RS. and Duda, LE., Radiation therapy in the treatment of canine and feline thymomas: A retrospective study (1985-1999). J Am Anim Hosp Assoc, 37:489-496, 2001.

25.Al-Zubaiday, AJ., Malignant thymoma with metastases in a dog, Vet Rec; 109:490-492, 1981.
SIMEONOVA G., et al.

26.Bellah, JR., Stiff, ME. and Russell, RG., Thymoma in the dog: Two case reports and review of 20 additional cases., J Am Vet Med Assoc,; 183: 306-31, 1983.

27.Isselbacher, KJ., Adams, RD., Branwald, E., Pet-Ersdorf, RG.and Wilson, JD., Harrison's principles of internal medicine, 9th ed. New York: McGraw-Hill Book Company, 1980

28. Tomazsek, S., Wigle, DA., Keshavjee, S. and Fisher, S., Thymomas: review of current clinical practice, Ann Thorac Surg, 87:1973-1980, 2009.

29.Hasserjian, RP., Ströbel, P. and Marx, A.. Pathology of thymic tumors. Semin Thorac Cardiovasc Surg., 17: 2-11, 2005.

30.Moffet, A.C., Metastatic thymoma and acquired generalized myasthenia gravis in a beagle. Can Vet J, 48: 91-93, 2007. 